\title{
TRICHOLOMA USTALOIDES (AGARICALES, BASIDIOMYCOTA) IN POLAND
}

\author{
Marek Halama ${ }^{1}$, Rafą Ważny, Matylda CzosnyKowsKa-ŁuKacka \\ $\&$ TADEUSZ DobOSZ
}

\begin{abstract}
The current distribution of Tricholoma ustaloides Romagn. in Poland is presented, based on literature data and the results of mycological investigations in oak-hornbeam forest associations in the Kotlina Raciborska basin. The paper reports the morphology of the discovered basidiomata, the habitat where they were found, and ITS sequence data for the specimens, and briefly discusses similar species and the ecology of the presented fungus. The location given in the paper is currently the only known station of T. ustaloides in Poland. The importance of secondary habitats for survival of this taxon is stressed.
\end{abstract}

Key words: chorology, ectomycorrhizal fungi, ITS sequence data, micromorphology, Poland

Marek Halama, Museum of Natural History, Wrocław University, H. Sienkiewicza 21, 50-335 Wroctaw, Poland; e-mail: marek.halama@uwr.edu.pl

Rafat Ważny, Małopolska Centre of Biotechnology, Jagiellonian University, Gronostajowa 7a, 30-387 Kraków, Poland

Matylda Czosnykowska-Lukacka \& Tadeusz Dobosz, Molecular Techniques Unit, Department of Forensic Medicine, Wrockaw Medical University, M. Curie-Skłodowskiej 52, 50-369 Wrocław, Poland

\section{INTRODUCTION}

The ectomycorrhizal genus Tricholoma (Fr.: Fr.) Staude comprises $c a 300$ species worldwide (Noordeloos \& Christensen 1999; Christensen \& Heilmann-Clausen 2013). These agarics are generally symbiotic with forest trees of the families Betulaceae, Fagaceae, Salicaceae and Pinaceae. In addition to the Tricholoma species that have a broad spectrum of partners, many apparently are limited to a particular host tree genus (Trappe 1962; Christensen \& Heilmann-Clausen 2013). There is only one euagarics clade of Agaricomycotina. The systematic unit Agaricomycotina (Hymenomycetes), is one of three taxa of the fungal division Basidiomycota. The euagarics clade includes forms with lamellate basidiocarps formerly classified in the Agaricales, but also forms with other hymenial configurations. Molecular phylogenetic studies have revealed a monophyly of Tricholoma (s.str.) within the euagarics clade of Agaricomycotina (Moncalvo et al. 2002; Sánchez-García et al. 2014). In Europe

\footnotetext{
1 Corresponding author
}

ca 70 Tricholoma species are known, and in Poland no fewer than 50 members of this genus have been found (Gminder \& Krieglsteiner 2001; Riva 2003; Wojewoda 2003). Tricholoma ustaloides Romagn. has not been recorded in Poland previously (Wojewoda 2003). A geographical distribution map of T. ustaloides in Europe (Christensen \& HeilmannClausen 2013) indicated its occurrence in Poland but without giving the source of the record or the exact location. The present paper describes the first collections of the species in Poland, made in the Łężczak Reserve in 2014. The species was identified on the basis of morphological analysis and ITS rDNA sequence data.

\section{MATERIAL AND METHODS}

\section{MORPHOLOGICAL STUDY}

Macroscopic features were studied from fresh material of four collections comprising 20 basidiomata in different stages of development. All microscopic structures were observed in dried material. Freehand sections of 
rehydrated pieces of basidiomata were examined in 5\% $\mathrm{NH}_{3} \cdot \mathrm{H}_{2} \mathrm{O}$ reagent with $1 \%$ Phloxine $\mathrm{B}$. Image-grabbing and biometric analyses were done with NIS-Elements D 3.1 imaging software. Dimensions of microcharacters are given as (minimum) average \pm standard deviation (maximum), and additionally as main data range (10-90 percentile values). The $Q$ value is the length/width ratio of basidiospores. For basidiospores size measurements, randomly selected mature spores were measured without the hilar appendix. The length of basidia was measured excluding sterigmata. Micrographs were taken using a Nikon digital camera (DS-Fil) digital camera. Statistical computations employed Statistica (StatSoft). Morphological terminology follows Vellinga (1988) and Vellinga and Noordeloos (1999). The studied collections are deposited in the Museum of Natural History, Wrocław University, Poland (WRSL).

\section{MOLECULAR PROCEDURES}

The fungal mycelium was isolated from the basidiocarp into pure cultures. DNA was extracted from mycelium samples with a Genomic Mini AX Plant Kit (A\&A Biotechnology) according to the manufacturer's instructions. Prior to sequencing, the ITS rDNA region (ITS1+5.8S+ITS2) was amplified using ITS1F (Gardes \& Bruns 1993) and ITS4 (White et al. 1990) primers. PCR conditions were optimized for the Maxima Hot Start Green PCR Master Mix (Thermo Scientific). Each reaction contained $10-100 \mu \mathrm{g} / \mu 1 \mathrm{DNA}, 9.5 \mu 1$ nuclease-free water, $12.5 \mu \mathrm{l}$ Master Mix and $1 \mu \mathrm{g} 10 \mathrm{pmol}$ of each primer. The total volume of each reaction was $25 \mu 1$. The PCR parameters were as follows: initial denaturation at $95^{\circ} \mathrm{C}$ for $3 \mathrm{~min}$, then denaturation at $95^{\circ} \mathrm{C}$ for $30 \mathrm{~s}$, annealing at $55^{\circ} \mathrm{C}$ for $30 \mathrm{~s}$, and extension at $72^{\circ} \mathrm{C}$ for $45 \mathrm{~s}$. This cycle was repeated 35 times. The final extension was carried out at $72^{\circ} \mathrm{C}$ for $5 \mathrm{~min}$. The PCR products were visualized by agarose electrophoresis. The ITS rDNA amplicons were sequenced with ITS4 primer by the Laboratory of Molecular Biology of Adam Mickiewicz University in Poznań (Poland). All obtained sequences were analyzed by Chromas (www.technelysium.com.au) and compared with the sequences deposited in the UNITE and NCBI databases using the BLASTn algorithm.

\section{RESULTS}

Tricholoma ustaloides Romagn.

Figs $1 \& 2$

Bull. Soc. Nat. Oyonnax 8: 76. 1954.

Basidiomata solitary, gregarious or subfasciculate. Pileus 20-100 mm, initially hemispherical

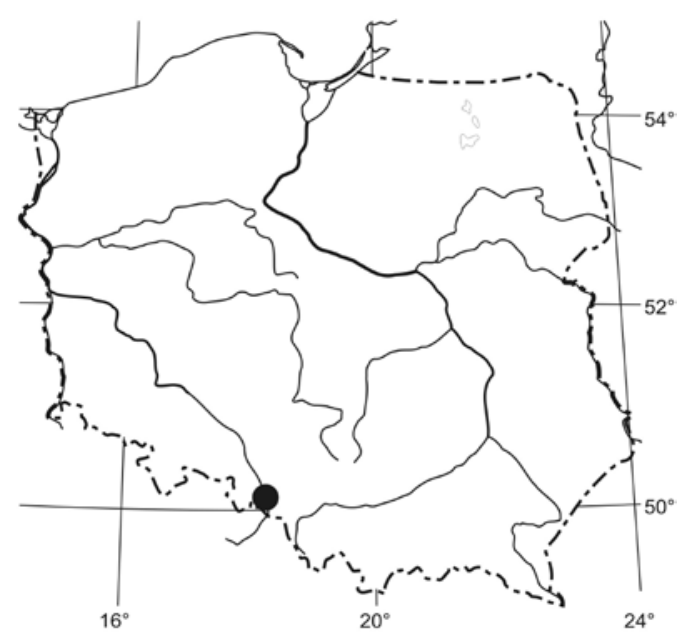

Fig. 1. Known distribution of Tricholoma ustaloides Romagn. in Poland.

to broadly campanulate, with strongly involute margin, then convex with low umbo, after which plano-convex, smooth or subsquamulose at the center in some basidiomata, margin somewhat lobed, involute, often sulcate in old basidiomata, orange brown to dark brick, sometimes with slightly paler margin, strongly glutinousviscid when moist, \pm sticky when dry. Lamellae, $\mathrm{L}=50-90,1=2-5$, moderately crowded, narrowly adnate to emarginate, subventricose to ventricose, white to cream when fresh, often with dark brown stains and spots near edges when old or bruised, with entire, concolorous edge. Stipe 30-100 $\times 10-25 \mathrm{~mm}$, fusiform, tapering upwards, subclavate, rooting, sometimes \pm swollen to bulbous towards base, smooth to fibrillose, rarely with appressed scales, generally dark pinkish buff to dark brick, usually at the top with rather distinctly and sharply delimited, 5-10 $\mathrm{mm}$ broad, white and almost smooth zone. Context whitish, often with brownish tinges near surface. Smell after cutting strongly farinaceous. Taste farinaceous and distinctly bitter, particularly the pileipellis. Basidiospores (4.5) $5.5 \pm 0.4(7.5) \times(4.0) 4.5 \pm 0.3$ (5.5) $\mu \mathrm{m}, 5.0-6.0 \times 4.5-5.0 \mu \mathrm{m}, \mathrm{Q}=(1.1) 1.2 \pm$ 0.1 (1.4), $\mathrm{Q}=1.1-1.3, \mathrm{n}=188$, subglobose to ellipsoid, with distinct hilar appendage (predominantly broadly ellipsoid), smooth, thin-walled. Basidia (26.5) $33.0 \pm 3.3(41.0) \times(6.5) 7.5 \pm 0.4$ 


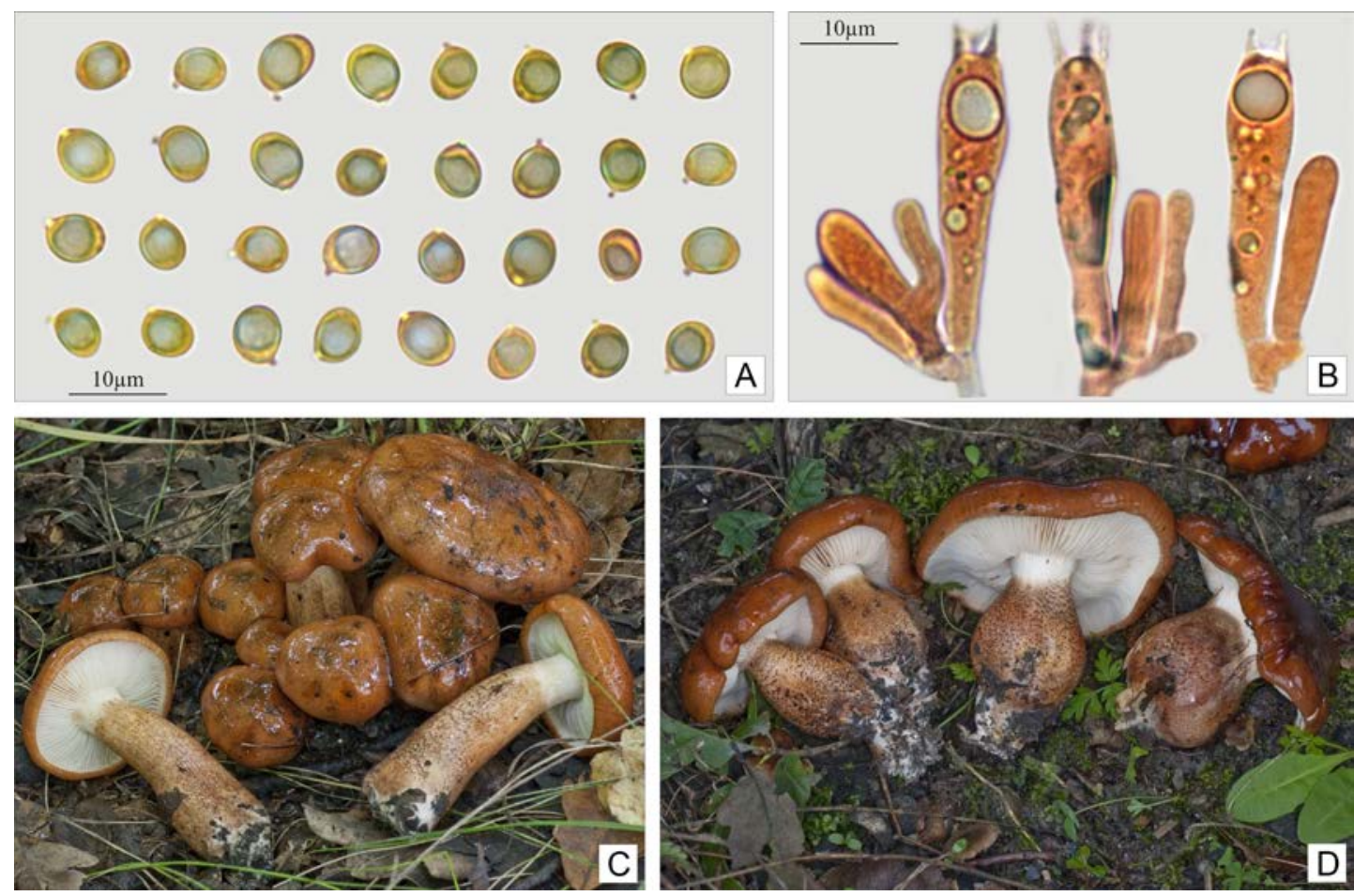

Fig. 2. Tricholoma ustaloides Romagn. A - basidiospores, B - basidia, D - top, side and bottom views of basidiomata (all photographed from WRSL MH-2014-0284).

(8.5) $\mu \mathrm{m}, 29.5-37.5 \times 7.0-8.0 \mu \mathrm{m}, \mathrm{n}=86$, narrowly clavate, $2-4$-spored. No cystidia observed. Pileipellis an ixocutis to an ixotrichoderm, made up of cylindrical hyphae embedded in gelatinous layer, 2.5-5.5 $\mu \mathrm{m}$ wide, with subclavate terminal elements. Pigment membranal and incrusting, mainly in suprapellis, also brown, intracellular in some terminal elements of pileipellis. No clampconnections seen.

Specimens eXamined: POLAND. Silesian LowLANDS, Kotlina Raciborska basin (Łężczak Reserve), on dam (between Babiczak Północny and Salm Duży ponds) - on Oak Alley: 1 - gregarious or subfasciculate on soil (raw humus) under Carpinus betulus L., Crataegus sp., Malus sylvestris Mill., Quercus sp. and Tilia cordata Mill., alt. $179 \mathrm{~m}$ a.s.l., $50^{\circ} 08^{\prime} 27^{\prime \prime} \mathrm{N}$, $18^{\circ} 16^{\prime} 57^{\prime \prime}$ E, 14 Sept. 2014, leg. M. Halama (WRSL MH-2014-0284), 2 - solitary, gregarious or subfasciculate on soil (humus covered by broadleaved litter) under Crataegus sp., Quercus sp. and Prunus spinosa L., alt. 179 m a.s.1., $50^{\circ} 08^{\prime} 27^{\prime \prime} \mathrm{N}, 18^{\circ} 16^{\prime} 56^{\prime \prime}$ E, 14 Sept. 2014, leg. M. Halama (WRSL MH-2014-0285), 3 - solitary, gregarious or subfasciculate on soil (humus covered by broadleaved litter and humus under herbaceous plants) under Quercus sp. and Tilia cordata, alt. $179 \mathrm{~m}$ a.s.1., $50^{\circ} 08^{\prime} 2.8^{\prime \prime} \mathrm{N}, 18^{\circ} 16^{\prime} 54^{\prime \prime} \mathrm{E}, 14$ Sept. 2014, leg. M. Halama (WRSL MH-2014-0286), 4 - solitary, gregarious or subfasciculate on soil (humus covered by broadleaved litter and humus under herbaceous plants) under Cerasus avium (L.) Moench, Prunus spinosa, Quercus sp., Rhamnus cathartica L. and Tilia cordata, alt. $179 \mathrm{~m}$ a.s.1., $50^{\circ} 08^{\prime} 30^{\prime \prime} \mathrm{N}, 18^{\circ} 16^{\prime} 48^{\prime \prime} \mathrm{E}, 14$ Sept. 2014 , leg. M. Halama (WRSL MH-2014-0287).

\section{MOLECULAR CHARACTERIZATION}

Sequencing of the ITS rDNA region of Tricholoma ustaloides yielded fragments $680 \mathrm{bp}$ long. The ITS sequence of the tested sample showed $99 \%$ similarity with the reference sequences of T. ustaloides deposited in the UNITE database as UDB000816, UDB015393 and UDB011564, and with erroneously named sequences of $T$. ustale (UDB000815) and T. fulvum (UDB015391), and 99\% similarity 
with the reference sequences of $T$. ustaloides deposited in NCBI GenBank database as LT000126 and LT000094. The obtained ITS sequence was deposited in the NCBI GenBank nucleotide database (Accession number: KX034212).

\section{DisCUSSION}

Tricholoma ustaloides is characterized by its orange-brown pileus and lower part of the stipe, rather sharply delimited white zone at the top of the stipe, and distinctly farinaceous and very bitter taste (especially in the cap cuticle). It also seems to be well characterized by having strongly glutinous caps when moist, a white context, rather moderately crowded lammelae, whitish or cream and often brownish stains near the lamella edges, in combination with predominantly broadly ellipsoid basidiospores. The morphology of the T. ustaloides specimens collected in Poland agrees with the description and drawings of Christensen and Heilmann-Clausen (2013). The observed occurrence of $T$. ustaloides with Quercus in clayey soil is also consistent with the overall ecological pattern of the species. The morphological identification is supported by similarity of the ITS sequence of one Polish specimen with sequences of $T$. ustaloides deposited in UNITE databases.

Tricholoma ustaloides is quite similar to T. ustale (Fr.: Fr.) P. Kumm. in having a similar general habit and a yellowish brown to brick pileus. The color of the pileus, however, usually has a rather paler, more yellowish component towards the margin, and the surface of the pileus is less viscid and typically not strongly glutinous. The latter species also differs by the mild taste of the pileipellis and the lack of a sharply delimited white zone at the top of the stipe. Although T. ustale is often reported from Quercus forests, it is a species particularly accompanying Fagus (Christensen \& Heilmann-Clausen 2013). Tricholoma quercetorum Contu recently described from Southern Europe (Contu 2003) is distinguished from $T$. ustaloides by the same characters as T. ustale (apart from the viscidity of the pileus), and additionally differs microscopically by having narrower spores $(5.5-7.0 \times 3.5-5.0 \mu \mathrm{m})$ (Christensen \& Heilmann-Clausen 2013). Another similar species, Tricholoma batschii Gulden, has, in common with T. ustaloides, a well-delimited white zone at the top of the stipe and similar colors of the basidiomata, but differs in having a thin but distinct, membranous and often wavy ring which soon becomes attached to the stipe. Furthermore, T. batschii grows with Pinus (rarely Cupressus), generally in dry, calcareous soil, and may be easily separated microscopically by its smaller basidiospores $(3.8-6.4 \times 3.1-5.4 \mu \mathrm{m})$ (Christensen \& Heilmann-Clausen 2013).

Tricholoma ustaloides has a wide geographical distribution in Europe, where it occurs from the Mediterranean up to southern Scandinavia. It has been reported from Southern Europe (Bulgaria, Corsica, Greece, Italy, Montenegro, Portugal, Sicily, Spain, Turkey), Western Europe (Belgium, France, the Netherlands), Central (Austria, Czech Republic, Germany, Hungary, Lichtenstein, Slovenia, Switzerland) and Northern Europe (Denmark, England, Estonia, Ireland, Norway, Scotland, Sweden) (Riva 1988; Zervakis et al. 1998; Christensen 1999; Tóth 1999; Gminder \& Krieglsteiner 2001; Denchev \& Assyov 2004; Jurc et al. 2004; Legon et al. 2005; Roux 2006; Walleyn et al. 2006; Baptista et al. 2010; Kalamees 2010; Běták 2011; Lazarević et al. 2011; Christensen \& Heilmann-Clausen 2012, 2013). It is generally rare in Northern Europe and much more common in countries with mild climates in Central and Southern Europe (Riva 1988; Christensen 1999). The northernmost records of the species do not exceed $59^{\circ} \mathrm{N}$, and the northern limit of T. ustaloides seems to follow the natural distribution of its main hosts (Quercus) (Gminder \& Krieglsteiner 2001; Kalamees 2010; Christensen \& HeilmannClausen 2013). Tricholoma ustaloides is also known to occur in North Africa (Morocco) and Asia (e.g., Turkey) (Malençon \& Bertault 1975; Gezer 2000; Courtecuisse \& Duhem 2007; Sesli \& Denchev 2008; Riva 2009). Villeneuve et al. (1989) indicated a similar species (as Tricholoma cf. ustaloides Romagn.) from North America (Canada, Quebec) but without any supplementary data. 
Most European localities of T. ustaloides are from $150-850 \mathrm{~m}$ a.s.l. and are confined to collinesubalpine vegetation zones (Pegler 1966; Breitenbach \& Kränzlin 1991; Noordeloos \& Christensen 1999; Gminder \& Krieglsteiner 2001; Laganà et al. 2002; Kalamees 2010; Kibby 2010; Ludwig 2012; Hernández-Rodríguez et al. 2013; this study). The highest elevation given in available data (1200-1300 m a.s.1.) is from Spain (Llorens van Waveren \& Llistosella 2005). Descriptions of the habitat of $T$. ustaloides vary widely from one locality to another and from region to region. Bearing in mind that the climate and the bedrock differ between various sites, the ectomycorrhizal plant hosts should also differ. The most common habitats in Northwestern and Central Europe are described by different authors as (thermophilic) deciduous forest, parks and pond dams, typically on (nutrient-rich) clayey, calcareous or loess soils, mainly under Quercus robur L., Q. petraea (Matt.) Liebl. and Fagus sylvatica L., rarely Carpinus betulus (Noordeloos \& Christensen 1999; Holec \& Beran 2006; Kibby 2010; Ludwig 2012; Christensen \& Heilmann-Clausen 2013). In Southern Europe the habitat of the species is generally described as thermophilic (silicolous, calcicolous) deciduous woodland, rarely orchards, with a preference for associations with oak, beech, chestnut and hornbeam (Bon 1984; Riva 1988; Bon 1991; Gminder \& Krieglsteiner 2001; Galli 2005; Roux 2006). Edaphic conditions range from acid to neutral and alkaline. Tricholoma ustaloides has frequently been characterized in southern regions as a calciphilous species, but there are a number of reports on neutral and acid ground (Bon 1984, 1991; Laganà et al. 2002; Galli 2005; Roux 2006; Ortega et al. 2010). There are several records on limestone, and its lithological substrates have been described variously as verrucano, sandstone, polychrome sericitic schist, rhyolitic lava flows, clastic quartzitic and phyllitic rocks, gabbro, polygenic conglomerates, periostite and serpentinite (Laganà et al. 2001; Laganà et al. 2002; Ortega et al. 2010). A broad spectrum of accompanying plants have been given, possible mycorrhiza symbionts for T. ustaloides in the Mediterranean region: Castanea sativa Mill., Corylus avellana L., Quercus canariensis Willd., Q. cerris L., Q. conferta Kit., $Q$. faginea Lam., Q. frainetto Ten., $Q$. humilis Lam., Q. ilex L., Q. pubescens Willd., Q. pyrenaica Willd. and Q. suber L. (Malençon \& Bertault 1975; Bon 1984; Riva 1988; Zervakis et al. 1998; Gminder \& Krieglsteiner 2001; Laganà et al. 2001; Laganà et al. 2002; Galli 2005; Llorens van Waveren \& Llistosella 2005; Comandini et al. 2006; Dimou et al. 2008; Baptista et al. 2010; Ortega et al. 2010). Also mentioned are associations of T. ustaloides with Cistus sp., Cistus ladanifer L., Juniperus oxycedrus L., Picea abies (L.) H. Karst. and Pinus sylvestris L. (Gminder \& Krieglsteiner 2001; Llorens van Waveren \& Llistosella 2005; Comandini et al. 2006; Dimou et al. 2008; Ludwig 2012; Hernández-Rodríguez et al. 2013), but these records may represent other taxa (e.g., T. ustale, T. batschii) and should be treated with caution.

Tricholoma ustaloides is considered threatened in several countries. It is on the red list of fungi in the Czech Republic in category DD (data deficient), in Denmark, the Netherlands, Norway and Switzerland it is classed as vulnerable (VU), and in Sweden as near threatened (NT) (Benkert et al. 1992; Holec \& Beran 2006; Senn-Irlet et al. 2007; Arnolds \& Veerkamp 2008; Dahlberg et al. 2010; Anonymous 2012). The only known locality of T. ustaloides in Poland is shown in Figure 1. In the neighboring Czech Republic the species is known from only a few localities (Holec \& Beran 2006). Its overall distribution in Poland is not known but most likely $T$. ustaloides is very rare here. This species is a possible candidate for the prospective red list of fungi in Poland; the DD (data deficient) threat category is tentatively proposed.

Particularly favorable geographic and climatic conditions in the Łężczak Reserve, combined with past economic activity which led to the development of tree-lined lanes along dams, have made this an important biodiversity area (Duda \& Wika 1994). The tree-lined lanes are the only Polish localities of several fungal species (Trząski 1994). At the locality of T. ustaloides along the Oak Alley, several other interesting ectomycorrhizal fungi were found, including Tricholoma sejunctum (Sowerby: Fr.) Quél., Aureoboletus gentilis (Quél.) Pouzar, Rubinoboletus rubinus (W. G. Sm.) Pilát 
\& Dermek, Caloboletus radicans (Pers.: Fr.) Vizzini, Boletus reticulatus Schaeff., B. aereus Bull.: Fr. and Leccinellum crocipodium (Letell.) Della Maggiora \& Trassinelli.

Acknowledgements. We thank Morten Christensen (Faculty of Life Science, Center for Forest, Landscape and Planning, University of Copenhagen, Denmark) for confirming the identification of Tricholoma ustaloides and for providing access to unpublished sequence data. We also thank Kornelia Arent for her invaluable help, and the anonymous reviewer for useful comments on the manuscript. This work was supported in part by the statutory fund of the Museum of Natural History of Wrocław University.

\section{REFERENCES}

Anonymous 2012. The Danish Red Data Book. [June 2012]. http://www2.dmu.dk/1_Om_DMU/2_Tvaer-funk/3_fdc_ bio/projekter/redlist/redlist_en.asp.

Arnolds E. \& Veerkamp M. 2008. Basisrapport Rode Lijst Paddenstoelen. Nederlandse Mycologische Vereniging, Utrecht.

Baptista P., Martins A., Tavares R. M. \& Lino-Neto T. 2010. Diversity and fruiting pattern of macrofungi associated with chestnut (Castanea sativa) in the Trás-os-Montes region (Northeast Portugal). Fungal Ecology 3(1): 9-19.

Benkert D., Dörfelt H., Hardtke H.-J., Hirsch G., KreiSel H., Krieglsteiner G. J., LüDeritz M., Runge A., Schmid H., Schmitt J. A., Winterhoff W., Wöldecke K., Zehfuss H.-D., Einhellinger A., Gross G., GrosseBrauckmann H., Nuss I. \& Wölfel G. 1992. Rote Liste der gefährdeten Großpilze in Deutschland. Deutsche Gesellschaft für Mykologie e.V. \& Naturschutzbund Deutschland e.V. (NABU), IHW-Verlag, Eching.

BĚŤÁK J. 2011. Some rare and less known species of macromycetes found in the Podyjí National Park in 2010. Thayensia (Znojmo) 8: 77-91 (in Czech with English summary).

Bon M. 1984. Les Tricholomes de France et d'Europe Occidentale. Editions Lechevalier S.A.R.L., Paris.

Bon M. 1991. Flore mycologique d'Europe 2: Les Tricholomes et ressemblants. Association d'Ecologie et de Mycologie, Lille.

Breitenbach J. \& Kränzlin F. 1991. Fungi of Switzerland. 3(1). Verlag Mykologia, Luzern.

Christensen M. 1999. Sveden Ridderhat (Tricholoma ustale) og Knippe-Ridderhat (T. ustaloides). Svampe 39: 42-46.

Christensen M. \& Heilmann-Clausen J. 2012. Tricholoma (Fr.) P. Kumm. In: H. KNUdSen \& J. Vesterholt (eds), Funga Nordica, pp. 494-510. Nordsvamp, Copenhagen.
Christensen M. \& Heilmann-Clausen J. 2013. The Genus Tricholoma. Fungi of Northern Europe. 4. Svampetryk, Oddense.

Comandini O., Contu M. \& Rinaldi A. 2006. An overview of Cistus ectomycorrhizal fungi. Mycorrhiza 16(6): 381-395.

Contu M. 2003. Entit rare, critiche o nuove del genere Tricholoma osservate in Sardegna, con segnalazione di due specie nuove per l'isola. Micol. Veg. Medit. 18(2): 91-100.

Courtecuisse R. \& Duhem B. 2007. Guide des champignons de France et d'Europe. Delachaux et Niestlé, Paris.

Dahlberg A., Krikorev M., Hansen K., Jacobsson S., JeppSON M., KNutsson T., KuOlJOK S., Larsson K.-H., Nordén B., Nitare J., Svensson S. \& Tedebrand J.-O. 2010. Svampar - Fungi. In: U. GÄRDENFORS (ed.), Rödlistade arter $i$ Sverige 2010 - The 2010 Red list of Swedish species, pp. 247-284. ArtDatabanken, SLU, Uppsala.

Denchev C. M. \& Assyov B. 2004. Checklist of the larger basidiomycetes in Bulgaria. Mycotaxon 111: 279-282.

Dimou D., Zervakis G. I. \& Polemis E. 2008. Mycodiversity studies in selected ecosystems of Greece: IV. Macrofungi from Abies cephalonica forests and other intermixed tree species (Oxya Mt., central Greece). Mycotaxon 104: 39-42.

Duda J. \& Wika S. 1994. Celowość utworzenia pomnikowej alei na obszarze rezerwatu Łężczak i w jego najbliższej okolicy. In: S. WiKa \& W. WŁoch (eds), Aleja Husarii Polskiej z alejami bocznymi na tle rezerwatu Łężczak w Kotlinie Raciborskiej. Scripta Rudensia 3: 13.

GALli R. 2005. I Tricolomi. Atlante practico-monografico per la determinazione del genere Tricholoma (Fr.) Staude. 2 ed. Edinatura, Milano.

GARDES M. \& BRUnS T. D. 1993. ITS primers with enhanced specificity for basidiomycetes - application to the identification of mycorrhizae and rusts. Molec. Ecol. 2(2): 113-118.

Gezer K. 2000. Contributions to the macrofungi flora of Antalya Province. Turkish Journal of Botany 24: 293-298.

Gminder A. \& Krieglsteiner G. J. 2001. Tricholomataceae Heim ex Pouzar 1983 (nom. cons.). In: G. J. KRIEGLSTEINER (ed.), Die Großpilze Baden-Württembergs. 3. Ständerpilze: Blätterpilze. I, pp. 117-588. Verlag Eugen Ulmer $\mathrm{GmbH} \&$ Co., Stuttgart.

Hernández-Rodríguez M., Oria-de-Rueda J. A. \& MartínPINTO P. 2013. Post-fire fungal succession in a Mediterranean ecosystem dominated by Cistus ladanifer L. Forest Ecol. Managem. 289: 48-57.

Holec J. \& Beran M. (eds) 2006. Red list of fungi (macromycetes) of the Czech Republic. Príroda (Prague) 24: 1-282 (in Czech with English summary).

Jurc D., Piltaver A. \& Ogris N. 2004. Seznam vrst in razširjenost makromicet $v$ Sloveniji z analizo stopnje ogroženosti-Končno poročilo. Gozdarski Inštitut Slovenije, Ljubljana. 
Kalamees K. 2010. Checklist of the species of the genus Tricholoma (Agaricales, Agaricomycetes) in Estonia. Folia Cryptog. Estonica 47: 27-36.

KiBBy G. 2010. The genus Tricholoma in Britain. Field Mycology 11(4): 113-140.

Laganà A., Salerni E., Barluzzi C. \& Perini C. 2001. Mycocoenological studies in some Mediterranean forest ecosystems (province of Siena, Italy). Ecol. Medit. 27(1): $125-140$.

Laganì A., Salerni E., Barluzzi C., de Dominicis V. \& PeRINI C. 2002. Fungi (macromycetes) in various types of Mediterranean forest ecosystems (Tuscany, Italy). Polish Bot. J. 47(2): 143-165.

Lazarević J., Perić O. \& Perić B. 2011. Ektomikorizne gljive u Crnoj Gori - diverzitet i distribucija. Mycol. Montenegrina 14: 85-115.

Legon N. W., Henrici A., Roberts P., Spooner B. M. \& Watling R. 2005. Checklist of the British and Irish Basidiomycota. Royal Botanic Gardens, Kew.

Llorens van Waveren L. \& Llistosella J. 2005. Fongs de Grélxer. Revista Catalana de Micologia 27: 131-151.

Ludwig E. 2012. Pilzkompendium. 3. Abbildungen. Die übrigen Gattungen der Agaricales mit weißem Sporenpulver. Fungicon Verlag, Berlin.

Malençon G. \& Bertault R. 1975. Flore des champignons supérieurs du Maroc. 2. Trav. Inst. Sci. Chérifien, Sér. Bot. Biol. Vég. 32: 1-539.

Moncalvo J.-M., Vilgalys R., Redhead S. A., Johnson J. E., James T. Y., Catherine Aime M., Hofstetter V., Verduin S. J. W., Larsson E., Baroni T. J., Greg Thorn R., JaCobsson S., Clémençon H. \& Miller O. K. JR. 2002. One hundred and seventeen clades of euagarics. Molec. Phylogenet. Evol. 23(3): 357-400.

Noordeloos M. E. \& Christensen M. 1999. Genus Tricholoma (Fr.: Fr.) Staude. In: C. BAS, T. W. KuYPER, M. E. Noordeloos \& E. C. Vellinga (eds), Flora Agaricina Neerlandica. 4: 107-148. A. A. Balkema Publishers, Rotterdam.

Ortega A., Lorite J. \& Valle F. 2010. Mycorrhizal macrofungi diversity (Agaricomycetes) from Mediterranean Quercus forests; a compilation for the Iberian Peninsula (Spain and Portugal). Nova Hedwigia 91(1-2): 1-31.

Pegler D. N. 1966. Additions to the Wild Fauna and Flora of the Royal Botanic Gardens, Kew: XXVII. A Revised List of the Agarics and Boleti. Kew Bull. 20(2): 201-231.

Riva A. 1988. Tricholoma (Fr.) Staude. Fungi Europaei. 3. Edizioni Candusso, Alassio.

Riva A. 2003. Tricholoma (Fr.) Staude. Supplemento. Fungi Europaei. 3a. Edizioni Candusso, Alassio.

Riva A. (ed.) 2009. Revisione e commento dei tricolomi di G. Malençon e R. Bertault Flore des Champignons Supé- rieurs de Maroc. 2. Confédération Européenne de Mycologie Méditerranéenne, Nice.

Roux P. 2006. Mille et un champignons. Édition Roux, Sainte-Sigolène.

Sánchez-García M., Matheny P. B., Palfner G. \& Lodge D. J. 2014. Deconstructing the Tricholomataceae (Agaricales) and introduction of the new genera Albomagister, Corneriella, Pogonoloma and Pseudotricholoma. Taxon 63(5): 993-1007.

SenN-Irlet B., Bieri G. \& EGLi S. 2007. Rote Liste der gefährdeten Grosspilze der Schweiz. Umwelt-Vollzug Nr. 0718. Bundesamt für Umwelt BAFU und der Eidgenössischen Forschungsanstalt für Wald, Schnee und Landschaft WSL, Bern, Birmensdorf.

Sesli E. \& Denchev C. M. 2008. Checklists of the Myxomycetes, larger Ascomycetes, and larger Basidiomycetes in Turkey. Mycotaxon 106: 65-67.

Tótн B. 1999. Mushrooms of the Gyepes-valley (HevesBorsod Hills, N-Hungary). Kitaibelia 4(2): 261-270 (in Hungarian with English summary).

Trappe J. M. 1962. Fungus associates of ectotrophic mycorrhizae. Bot. Rev. 28(4): 538-606.

TrZąSKi L. 1994. Analiza zasiedlania opisywanych alei przez grzyby wielkoowocnikowe rozkładające drewno. In: S. Wika \& W. WŁoch (eds), Aleja Husarii Polskiej $z$ alejami bocznymi na tle rezerwatu Łężczak w Kotlinie Raciborskiej. Scripta Rudensia 3: 28-36.

Vellinga E. C. 1988. Glossary. In: C. Bas, T. W. Kuyper, M. E. Noordeloos \& E. C. Vellinga (eds), Flora Agaricina Neerlandica. 1: 54-64. A. A. Balkema Publishers, Rotterdam.

Vellinga E. C. \& Noordeloos M. E. 1999. Glossary. In: C. Bas, T. W. Kuyper, M. E. Noordeloos \& E. C. VelLINGA (eds), Flora Agaricina Neerlandica. 4: 6-12. A. A. Balkema Publishers, Rotterdam.

Villeneuve N., Grandtner M. M. \& Fortin J. A. 1989. Frequency and diversity of ectomycorrhizal and saprophytic macrofungi in the Laurentide Mountains of Quebec. Canad. J. Bot. 67(9): 2616-2629.

Walleyn R., Antonissen I., de HaAn A., De HaAn M., De Keyser J., Hendrickx H., Lachapelle J., Le Jeune G., Mervielde H., Noten L., Schoutteten J., van de Kerckhove O., van de Put K., Verbeken A., Volders J., Lenaerts L., Monnens J., Termonia W., Van der Veken P., Van Ryckegem G., Vandeven É., Beker H., Bogaerts A., De Kesel A., De Pauw S., Dielen F., Ghyselinck D., Hanssens C. \& Vannieuwerburgh L. 2006. Standaardlijst van Basidiomycota en Myxomycota van Vlaanderen en het Brussels Gewest. In: R. WALleyn \& É. VANDEVEN (eds), Standaardlijst van Basidiomycota en Myxomycota van Vlaanderen en het Brussels Gewest. Rapport INBO.R.2006.27, pp. 1-143 + errata. Instituut voor Natuuren Bosonderzoek, Brussel. 
White T. J., Bruns T., Lee S. \& Taylor J. 1990. Amplification and direct sequencing of fungal ribosomal RNA genes for phylogenetics. In: M. A. InNIS, D. H. Gelfand, J. J. SNinsky \& T. J. White (eds), PCR Protocols: a guide to methods and applications, pp. 315-322. Academic Press, New York.
WoJEWODA W. 2003. Checklist of Polish Larger Basidiomycetes. Biodiversity of Poland 7. W. Szafer Institute of Botany, Polish Academy of Sciences, Kraków.

Zervakis G. I., Dimou D. \& Balis C. 1998. A check-list of the Greek macrofungi, including hosts and biogeographic distribution: I. Basidiomycotina. Mycotaxon 66: 273-336.

Received 16 June 2015 